\title{
EMISSION FACTOR ASSESSMENT FOR TWO FIREWOOD STOVES
}

\author{
RITA STURMLECHNER, HARALD STRESSLER, MANUEL SCHWABL, GABRIEL REICHERT, \\ ELISA CARLON, WALTER HASLINGER, CHRISTOPH SCHMIDL \& ALEXANDER WEISSINGER \\ BIOENERGY 2020+ GmbH, Area Combustion, Austria
}

\begin{abstract}
This study analyses the emission factors of two firewood room heaters under testing conditions which emulate real life operation. A $6.5 \mathrm{~kW}$ stove with low heat storage capacity and high leakage rate (stove A) is compared with an $8 \mathrm{~kW}$ air-tight stove with high heat storage capacity (stove B). Thermal efficiency, carbon monoxide (CO) and organic gaseous compound (OGC) emissions, as well as the thermal heat losses (THL) during cool down phase were investigated in a series of laboratory tests. Furthermore, the influence of closing the air supply dampers at the end of the heating cycle was evaluated. Test results for the whole test cycle (including cool down phase) showed that stove A had $\mathrm{CO}$ emissions of $2633 \mathrm{mg} / \mathrm{MJ}_{\text {Output }}$ and OGC emissions of $203 \mathrm{mg} / \mathrm{MJ}_{\text {Output, while stove B had CO }}$ emissions of $2408 \mathrm{mg} / \mathrm{MJ}_{\text {Output }}$ and OGC emissions of $109 \mathrm{mg} / \mathrm{MJ}_{\text {Output, when }}$ air dampers were closed. It was also found that user behaviour has a critical influence on the stoves' performance. Closing the air supply dampers at the end of the stove operation improved the efficiency by up to 5.0 percentage points. Furthermore, the duration of the cool down phase increased, as well as CO and OGC emissions decreased. As a matter of fact, measures to improve the user behaviour as for example user trainings and accurate manuals are of major importance in order to decrease emissions and increase efficiency of domestic heating appliances. Moreover, real life emission factors of other technologies should be established in order to develop a database which can be applied in air quality dispersion models.

Keywords: combustion, firewood, room heater, emission factor, thermal efficiency, thermal heat losses, heat storage capacity, user influence, real life.
\end{abstract}

\section{INTRODUCTION}

Firewood stoves are widely used all over Europe as domestic heating systems. However, in recent years, major concerns were raised about the emissions from wood combustion in the residential sector. Besides particle matter (PM), also carcinogenic compounds like polycyclic aromatic hydrocarbons (PAHs), e.g. Benzo(a)pyrene (BaP), are emitted during wood combustion and have an adverse effect on human health [1], [2].

Thus, air quality prediction models need to include emissions from biomass combustion sources. For example, Chiesa et al. [3] evaluated the influence of the replacement of old pellet boilers with new technologies in real life operation on air quality using a prediction model. For this purpose, it is essential to provide reliable data concerning the emissions of wood burning appliances under real life operating conditions. This task is particularly challenging because of the variety of combustion appliances available on the market and because of the different ways in which users operate their stoves.

Currently, emission factors for firewood room heaters are determined by field testing. For example, Spitzer et al. [4] identified mean emission factors for firewood and coal domestic heating appliances by testing 180 stoves and boilers in a field testing campaign, in Austria. Nevertheless, frame conditions (e.g. weather), appliances and especially user behaviour during field testing are random. Laboratory tests which rely on studies on typical user behaviour and defined stove characteristics would guarantee a more accurate and also repeatable result for emission factors. For instance, such laboratory tests are conducted by Meier et al. [5], who measured emission factors for $\mathrm{BaP}$ in small scale biomass combustion 
boilers under specific operation modes. Ozgen et al. [6] investigated ultrafine particle emissions and their chemical composition of two biomass room heaters operated under conditions similar to those found under real life.

Wöhler et al. [7] investigated typical user behaviour in Europe by means of an international survey with more than 2000 respondents. They identified user habits of firewood and pellet room heating appliances, regarding their heating operation, e.g. number of batches, air supply damper settings, seasonal operation, used fuel, etc. Typical user behaviour was also investigated by Reichert et al. [8] in a regional study focused on Austria. Only limited information is available regarding the influence of user behaviour on emissions and efficiency of room heating appliances. Reichert et al. [9] showed the influence of different ignition modes on combustion performances of firewood stoves. Mitchell et al. [10] investigated the impact of different fuel parameters on biomass combustion emissions.

This study investigates the emission factors of two firewood room heaters, with different properties. Thereby, the test cycle reflects typical user behaviour during heating season. The objectives of the study are:

- Emission factor assessment and comparison of two different firewood room heaters,

- Evaluation of the impact of the heat storage capacity of the stove on gaseous emissions, thermal efficiency and THL in the cool down phase,

- Testing two different user behaviours (open/closed air supply dampers at the end of heating operation) and evaluating their influence on gaseous emissions, thermal efficiency and THL in the cool down phase.

\section{MATERIALS AND METHODS}

\subsection{Tested stoves}

Two commercially available firewood room heaters with different heat storage capacity and different air leakage rate were tested. Table 1 shows the dimensions and main properties of the tested appliances. Stove A has a nominal thermal heat output (THO) of $6.5 \mathrm{~kW}$ and a low heat storage capacity. Stove B, having a nominal THO of $8 \mathrm{~kW}$ is almost 4 times heavier and partly covered with soap stones, which act as heat storage. Therefore, Stove B has a higher heat storage capacity. The leakage rates of both stoves were determined in a tightness test carried out at $10 \mathrm{~Pa}$ overpressure. Stove $\mathrm{B}$ is a room sealed appliance and has a leakage rate of $1.8 \mathrm{~m}^{3} / \mathrm{h}$, whereas stove A shows a much higher leakage rate $\left(14.4 \mathrm{~m}^{3} / \mathrm{h}\right)$.

Table 1: Overview on the properties of the tested appliances.

\begin{tabular}{|l|l|l|}
\hline & Stove A & Stove B \\
\hline $\begin{array}{l}\text { Thermal heat output } \\
\text { (acc. EN 13240) }\end{array}$ & $6.5 \mathrm{~kW}$ & $8 \mathrm{~kW}$ \\
\hline Height & $98 \mathrm{~cm}$ & $134 \mathrm{~cm}$ \\
\hline Width & $43 \mathrm{~cm}$ & $68 \mathrm{~cm}$ \\
\hline Length & $56 \mathrm{~cm}$ & $62 \mathrm{~cm}$ \\
\hline Weight & $88 \mathrm{~kg}$ & $\begin{array}{l}331 \mathrm{~kg} \text { (with soap stones) } \\
262 \mathrm{~kg} \text { (without soap stones) }\end{array}$ \\
\hline Material & Steel & Steel and soap stones \\
\hline $\begin{array}{l}\text { Overall heat storage } \\
\text { capacity }\end{array}$ & $44 \mathrm{~kJ} / \mathrm{K}$ & $\begin{array}{l}199 \mathrm{~kJ} / \mathrm{K} \text { (with soap stones) } \\
132 \mathrm{~kJ} / \mathrm{K} \text { (without soap stones) }\end{array}$ \\
\hline Leakage rate at $10 \mathrm{~Pa}$ & $14.4 \mathrm{~m}^{3} / \mathrm{h}$ & $1.8 \mathrm{~m}^{3} / \mathrm{h}$ \\
\hline
\end{tabular}




\subsection{Experimental setup}

All tests were carried out in a calorimeter room, as shown in the scheme of Fig. 1. The calorimeter room is a $2.7 \times 2.6 \times 3.4 \mathrm{~m}(\mathrm{~L} \mathrm{x} \mathrm{B} \mathrm{x} \mathrm{H)} \mathrm{insulated} \mathrm{closed} \mathrm{cabin,} \mathrm{where} \mathrm{input} \mathrm{and}$ output energy flows are measured and providing data to calculate the complete energy balance of the room. Table 2 shows the energy in- and outflows of the calorimeter room and Table 3 depicts the applied measurement equipment and its properties.

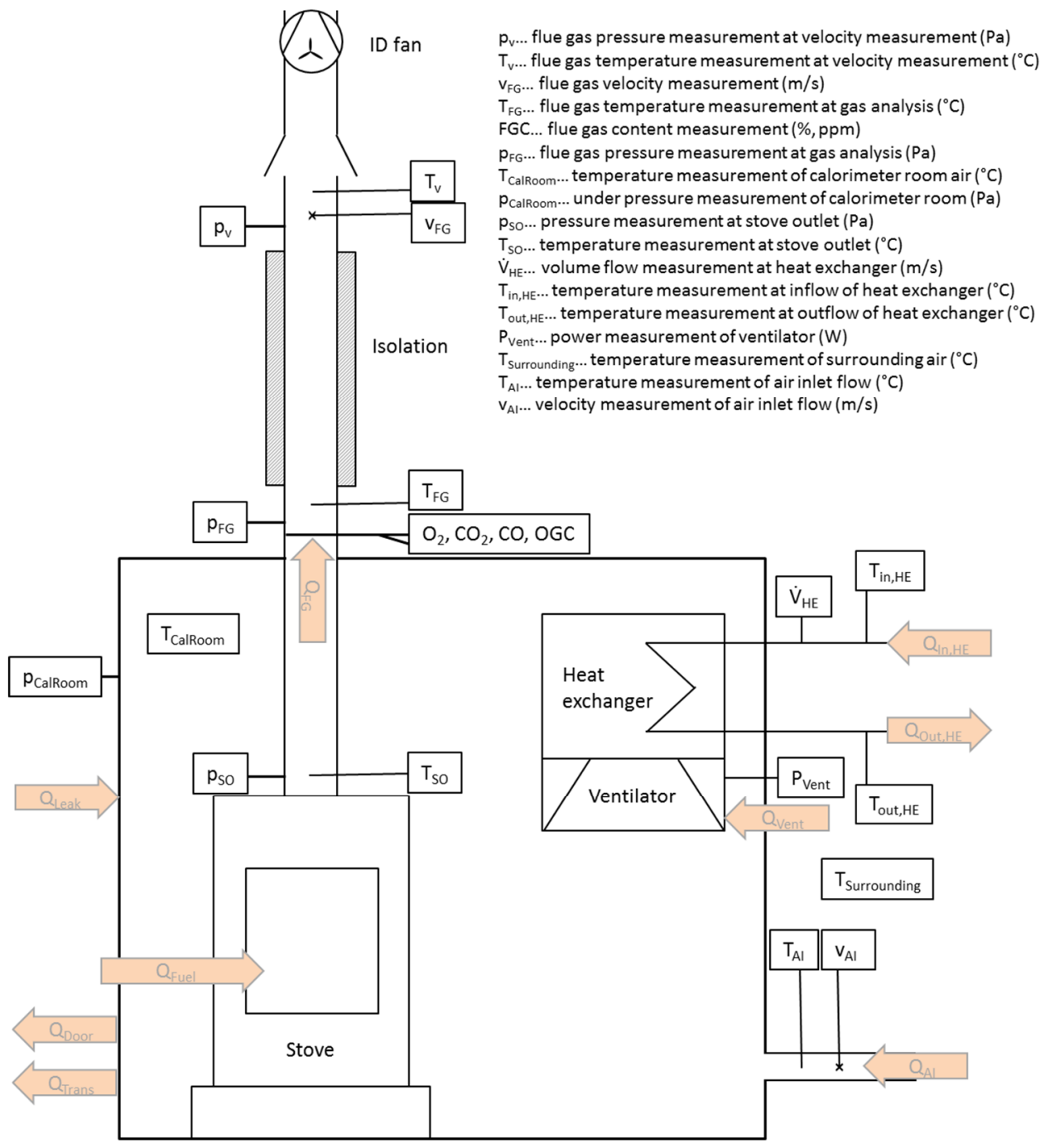

Figure 1: Scheme of the experimental set up in the calorimeter room. 
Table 2: Energy in- and outflows of the calorimeter room.

\begin{tabular}{|l|l|}
\hline Energy inflows & Energy outflows \\
\hline Qfuel: Fuel energy input (eqn (13)) & $\begin{array}{l}\text { Qout,HE: Output flow of heat exchanger } \\
\text { (QHE...eqn (6)) }\end{array}$ \\
\hline $\begin{array}{l}\text { QAI: Energy input through air inlet of the } \\
\text { calorimeter room (eqn (8)) }\end{array}$ & QFG: Flue gas losses (eqn (16)) \\
\hline $\begin{array}{l}\text { QIn,HE: Input flow of heat exchanger (QHE... } \\
\text { eqn (6)) }\end{array}$ & $\begin{array}{l}\text { QTrans: Transmission energy losses through } \\
\text { calorimeter room (QT\&D...eqn (15)) }\end{array}$ \\
\hline Qvent: Electric energy of ventilator (eqn (7)) & $\begin{array}{l}\text { QDoor: Energy losses through door opening } \\
\text { (QT\&D...eqn (15)) }\end{array}$ \\
\hline $\begin{array}{l}\text { QLeak: Energy input through leakage air } \\
\text { (eqn (9)) }\end{array}$ & \\
\hline
\end{tabular}

Table 3: Overview of used measurement equipment (principle, measured parameters and measuring range).

\begin{tabular}{|c|c|c|c|}
\hline Measurement equipment & Measurement principle & $\begin{array}{l}\text { Measured } \\
\text { parameters }\end{array}$ & $\begin{array}{l}\text { Measuring range and } \\
\text { (accuracy) }\end{array}$ \\
\hline \multirow{3}{*}{$\begin{array}{l}\text { Gas analyzer (Horiba } \\
\text { PG-350 E) }\end{array}$} & Paramagnetic cell & $\mathrm{O}_{2}$ & $0-25 \%( \pm 1 \%)$ \\
\hline & $\begin{array}{l}\text { Light-modulation and } \\
\text { IR-absorption }\end{array}$ & $\mathrm{CO}_{2}$ & $0-30 \%( \pm 1 \%)$ \\
\hline & $\begin{array}{l}\text { Fluid-modulation and } \\
\text { IR-absorption (NDIR) }\end{array}$ & $\mathrm{CO}$ & $\begin{array}{l}0-5000 \mathrm{ppm} \\
( \pm 1 \%)\end{array}$ \\
\hline FID (M\&A Thermo-FID) & Flame ionization & OGC & $\begin{array}{l}0-10000 \mathrm{ppm}(<4 \% \text { of } \\
\text { reading })\end{array}$ \\
\hline $\begin{array}{l}\text { Thermocouple (Type K, } \\
\text { class 1) }\end{array}$ & Seebeck-effect & \begin{tabular}{|l|}
$\mathrm{T}_{\mathrm{FG}} . \mathrm{T}_{\mathrm{v}}$, \\
T$_{\text {CalRoom }}, \mathrm{T}_{\mathrm{AI}}, \mathrm{T}_{\mathrm{SO}}$, \\
TS $_{\text {urrounding }}$ \\
\end{tabular} & $-50-+1000^{\circ} \mathrm{C}\left( \pm 1.5^{\circ} \mathrm{C}\right)$ \\
\hline Pt100 (class A) & resistance thermometer & TOut,HE, $\mathrm{T}_{\text {In,HE }}$ & $\begin{array}{l}-200-+850^{\circ} \mathrm{C} \\
\left( \pm 0.35^{\circ} \mathrm{C}\right)\end{array}$ \\
\hline $\begin{array}{l}\text { Pressure sensor (Halstrup } \\
\text { Walcher P92/PS10) }\end{array}$ & Inductive & $\begin{array}{l}\mathrm{P}_{\mathrm{FG}}, \mathrm{P}_{\mathrm{v}}, \mathrm{P}_{\mathrm{SO}}, \\
\mathrm{P}_{\text {CalRoom }}\end{array}$ & $-100-+100 \mathrm{~Pa}( \pm 4 \%)$ \\
\hline $\begin{array}{l}\text { Velocity measurement at } \\
\text { air inlet (LMS E+E 75) }\end{array}$ & Hot-wire anemometry & VAI & $0.15-10 \mathrm{~m} / \mathrm{s}( \pm 0.1 \mathrm{~m} / \mathrm{s})$ \\
\hline $\begin{array}{l}\text { Velocity measurement in } \\
\text { flue gas (Höntzsch) }\end{array}$ & Vane anemometry & VFG & $\begin{array}{l}0-20 \mathrm{~m} / \mathrm{s}(<1.5 \% \text { of } \\
\text { reading })\end{array}$ \\
\hline $\begin{array}{l}\text { Electric power mea- } \\
\text { surement (Janitza UMG } \\
604 \text { ) }\end{array}$ & Digital wattmeter & PVent $_{\text {Vent }}$ & $0-5$ A (class $0.5 \mathrm{~S}$ ) \\
\hline $\begin{array}{l}\text { Volume flow } \\
\text { measurement (End-ress } \\
\text { Promag 50P) }\end{array}$ & $\begin{array}{l}\text { Magnetic-inductive } \\
\text { velocity measurement }\end{array}$ & $\dot{\mathrm{V}}_{\mathrm{HE}}$ & $0-20 \mathrm{l} / \mathrm{min}( \pm 2 \mathrm{ml} / \mathrm{min})$ \\
\hline $\begin{array}{l}\text { Balance (Mettler-Toledo } \\
\text { BBK422-35LA) }\end{array}$ & Compact scale & $\mathrm{m}_{\text {Fuel }}$ & $5 \mathrm{~g}-34 \mathrm{~kg}(0.1 \mathrm{~g})$ \\
\hline $\begin{array}{l}\text { Leakage rate } \\
\text { measurement (Wöhler } \\
\text { DP 600) }\end{array}$ & $\begin{array}{l}\text { Volume flow at } \\
\text { over/under pressure }\end{array}$ & $\dot{\mathrm{V}}_{\text {Leak }}$ & $\begin{array}{l}0-10 / 200 \mathrm{~m}^{3} / \mathrm{h}(0.01 / 0.1 \\
\left.\mathrm{m}^{3} / \mathrm{h}\right) \\
0-900 / 7000 \mathrm{~Pa}(0.1 / 1 \mathrm{~Pa})\end{array}$ \\
\hline
\end{tabular}




\subsection{Test procedure}

In total 5 test runs were conducted. First, two different procedures for both stoves:

- One test run with open air supply dampers after heating operation,

- One test run with closed air supply dampers after heating operation.

Furthermore, to evaluate the influence of the heat storage capacity separately the following test was conducted:

- One test run without soap stone material of stove B and closed air supply damper settings after heating operation.

Each test run consisted of 3 consecutive batches, starting from cold conditions, and included the cool down phase of the stove (this test cycle represents a typical end user heating day in spring or autumn season [7]). Refilling criterion or the end of a batch was specified according to the $\mathrm{CO}_{2}$ content of the flue gas, precisely, when the $\mathrm{CO}_{2}$ content of the flue gas reached $25 \%$ of the maximum $\mathrm{CO}_{2}$ level of the respective batch or at $3 \%$ absolute $\mathrm{CO}_{2}$ level (when the maximum $\mathrm{CO}_{2}$ level didn't exceed 12\%). Previous measurements showed that this refilling criterion corresponds well with the qualitative criterion of "brightly visible flames are gone", which is common in real life [7].

Wöhler et al. [7] showed that hardwood is most commonly used as firewood. Thus, beech was used as fuel, and spruce kindling material and bio-based starting aids were used for ignition of the first batch. Table 4 shows the fuel analysis and the used amount of beech firewood for each stove. The ignition procedure was done according to the user manual of the respective stove (bottom-up ignition in both cases). During ignition, the air supply dampers for primary and secondary air were set to fully open. After the ignition batch, dampers were set to the recommended adjustment according to the user manual. Draught of the stack was automatically controlled to achieve a constant value of $12 \pm 2 \mathrm{~Pa}$ during heating operation. At the end of the third batch, the power setting of the ID fan was fixed on the current power level. This was done that the draught can slowly decrease dependent on temperature conditions in the combustion chamber. Thus, it enables draught conditions close to natural conditions during cool down.

All data were measured and logged in an interval of one second.

Table 4: Fuel analysis and amount of used fuel for both stoves at the conducted batches.

\begin{tabular}{|c|c|c|c|c|c|c|}
\hline & $C(\%$ d.b. $)$ & $H(\%$ d.b. $)$ & $N(\%$ d.b. $)$ & Ash (\%d.b.) & $\mathrm{H}_{2} \mathrm{O}(\%)$ & $H_{u}\left(\mathrm{~kJ} / \mathrm{kg}_{\text {d.b. }}\right)$ \\
\hline Beech & 49.07 & 6.02 & 0.1 & 0.94 & 13.6 & 18120 \\
\hline & $1^{\text {st }}$ batch & $2^{\text {nd }}$ batch & $3^{\text {rd }}$ batch & & & \\
\hline Stove A & $2.0 \mathrm{~kg}$ & $1.4 \mathrm{~kg}$ & $1.4 \mathrm{~kg}$ & & & \\
\hline Stove B & $2.0 \mathrm{~kg}$ & $2.0 \mathrm{~kg}$ & $2.0 \mathrm{~kg}$ & & & \\
\hline
\end{tabular}

\subsection{Evaluation}

Emissions and thermal efficiency were calculated for each entire test cycle. The end of the evaluation period of a test cycle was defined as the point when $95 \%$ of the total dissipated heat was reached, which was detected in the heat exchanger of the calorimeter room. 
Prior to the calculation of emission factors, the raw data mean values for the concentrations of $\mathrm{X}=\mathrm{CO}, \mathrm{OGC}, \mathrm{CO}_{2}$ and $\mathrm{O}_{2}$ were volume-weighted:

$$
X_{\text {mean }}=\frac{\sum\left(X_{\text {measured }} * \dot{V}\right)}{\sum \dot{V}} \text {. }
$$

The volume weighted parameters of $\mathrm{CO}$ and OGC were then evaluated according to the equations in EN 13240 standard [11] in $\mathrm{mg} / \mathrm{m}^{3}, \mathrm{STP}$, dry, $13 \% \mathrm{O}_{2}$ and converted into $\mathrm{mg} / \mathrm{MJ}$ Output as follows:

$$
C O_{\left(m g / M J_{-} I n p u t\right)}=C O_{\left(m g / m^{3}, S T P, d r y, 13 \% O 2\right)} V_{\min } \frac{0.21}{0.21-0.13} \frac{1}{H_{u}},
$$

in which $V_{\min }$ has a value of...3.85 $\mathrm{m}^{3} \mathrm{STP} / \mathrm{kg}_{\text {Fuel }}$ according combustion calculation. Moreover, thermal efficiency was integrated in the emission factor calculation:

$$
C O_{(\text {mg/MJ_Output })}=\frac{C O_{(m g / M J I n p u t)}}{\eta_{\text {thermal }}} \text {. }
$$

Thermal efficiency $\left(\eta_{\text {thermal }}\right)$ was evaluated by balancing the energy flows of the calorimeter room. Efficiency is defined as the ratio of useable output $\left(Q_{\text {output }}\right)$ and expended input energy $\left(Q_{\text {Input }}\right)$.

$$
\eta_{\text {thermal }}=\frac{Q_{\text {Output }}}{Q_{\text {Input }}}
$$

Thus, eqn (4) can be written as follows:

$$
\eta_{\text {thermal }}=\frac{Q_{H E}-Q_{V e n t}-Q_{A I}-Q_{\text {Leak }}+Q_{T \& D}}{Q_{\text {Fuel }}},
$$

in which the heat exchanger energy flow is calculated as follows:

$$
\dot{Q}_{H E}=\dot{V}_{H E} \rho_{H 2 O} c_{p, H 2 O}\left(T_{O u t, H E}-T_{I n, H E}\right) \text {. }
$$

The specific heat capacity $\left(c_{p, H 2 O}\right)$ and the density of water $\left(\rho_{H 2 O}\right)$ are temperature compensated according the average temperature of the heat exchanger in- and outflow.

The contribution of the ventilation system is calculated according to the following equation:

$$
Q_{\text {Vent }}=\int P_{\text {Vent }} d t
$$

The air inlet energy flow is evaluated as described in the following equation:

$$
\dot{Q}_{A I}=v_{A I} A_{A I} \rho_{\text {Air }} c_{p, \text { Air }}\left(T_{A I}-T_{\text {CalRoom }}\right) .
$$

Here, the specific heat capacity of air $\left(c_{p, A i r}\right)$ is based on a temperature of $25^{\circ} \mathrm{C}$. Air density of the air inlet $\left(\rho_{\text {Air }}\right)$ is temperature compensated.

The energy flow of the calorimeter room leakage is calculated similarly:

$$
\dot{Q}_{\text {Leak }}=\dot{m}_{\text {Leak }} c_{p, \text { Air }}\left(T_{\text {Surrounding }}-T_{\text {CalRoom }}\right) \text {, }
$$

whereas, the mass flow of the leakage $\left(\dot{m}_{\text {Leak }}\right)$ was evaluated in a pretest as a function of under pressure of the cabin. Thereby, the leakage volume flow rate of the calorimeter room was measured at different pressure levels at ambient air temperature conditions, using a leakage testing device (Wöhler DP 600). As a result a function of volume flow depending on pressure conditions in the calorimeter room could be determined (eqn (11)). So, the mass flow could be calculated accordingly: 


$$
\begin{gathered}
\dot{m}_{\text {Leak }}=\dot{V}_{\text {Leak }} \rho_{\text {Air }}, \\
\dot{V}_{\text {Leak }}=-0.0113 P_{\text {CalRoom }}^{2}+0.8867 P_{\text {CalRoom }}+0.1742 .
\end{gathered}
$$

Finally, each energy flow $\left(\dot{Q}_{H E}, \dot{Q}_{A I}, \dot{Q}_{L e a k}\right)$ is integrated to get the total amount of energy during the heating cycle.

$$
Q=\int \dot{Q} d t
$$

The expended input energy - the total fuel burnt - was calculated out of the total fuel mass of all batches and the net calorific value of the fired fuel.

$$
Q_{\text {Fuel }}=m_{\text {Fuel }} H_{\text {u,fuel }} .
$$

The energy amount due to transmission of the calorimeter room and due to energy losses through opening the door could not be determined directly. Therefore, an overall balance assessment of the calorimeter room was applied. As energy inflows $\left(Q_{\text {Inflows }}\right)$ and energy outflows $\left(Q_{\text {Outflows }}\right)$ need to be of the same amount, the energy of transmission and door opening $\left(\mathrm{Q}_{\mathrm{T} \& \mathrm{D}}\right)$ could be evaluated as follows:

$$
\begin{gathered}
Q_{\text {Inflows }}=Q_{\text {outflows }}, \\
Q_{T \& D}=Q_{\text {Fuel }}+Q_{A I}+Q_{\text {Leak }}-Q_{H E}+Q_{\text {Vent }}-Q_{F G},
\end{gathered}
$$

in which the flue gas energy $\left(\mathrm{Q}_{\mathrm{FG}}\right)$, which represents the THL, are calculated according to:

$$
\dot{Q}_{F G}=v_{F G} A_{F G} \rho_{F G} c_{p, F G}\left(T_{F G}-T_{\text {CalRoom }}\right) \text {. }
$$

The heat energy flow was also integrated according to eqn (12). The specific heat capacity $\left(c_{p, F G}\right)$ and the density of the flue gas $\left(\rho_{F G}\right)$ are, based on standard values for air, temperature compensated. The influence of $\mathrm{CO}_{2}$ and $\mathrm{H}_{2} \mathrm{O}$ was neglected for the $c_{p, F G}$ calculation.

\section{RESULTS}

Emission factors and efficiencies measured for the whole test cycle are reported in Table 5. Firstly, the results for both stoves of the tests with closed air supply dampers are compared. Results show that stove A has a higher efficiency ( $78 \%$, compared to $73 \%$ of stove B), but also higher emissions (especially OGC). Differences in thermal efficiencies may result from

\begin{tabular}{|c|c|c|c|c|c|}
\hline & \multirow[b]{2}{*}{$\begin{array}{l}\eta_{\text {thermal }} \\
(\%)\end{array}$} & \multirow[b]{2}{*}{$\begin{array}{l}\text { CO } \\
\left(\mathrm{mg} / \mathrm{MJ}_{\text {Output }}\right)\end{array}$} & \multirow[b]{2}{*}{$\begin{array}{l}O G C \\
\left(\mathrm{mg} / \mathrm{MJ}_{\text {Output }}\right)\end{array}$} & \multicolumn{2}{|c|}{ Cool down } \\
\hline & & & & $\begin{array}{l}\text { Duration } \\
\text { (h:mm) }\end{array}$ & $\begin{array}{l}\text { Share of THL } \\
(\%)\end{array}$ \\
\hline Stove $\mathrm{A}$ - closed & 78.0 & 2633 & 203 & $3: 09$ & 25.4 \\
\hline Stove B - closed & 73.3 & 2408 & 109 & $4: 16$ & 15.1 \\
\hline Stove A - open & 76.9 & 3162 & 247 & $2: 53$ & 28.4 \\
\hline Stove B - open & 68.3 & 3754 & 162 & $3: 46$ & 33.7 \\
\hline $\begin{array}{l}\text { Stove B - closed, } \\
\text { without soap stones }\end{array}$ & 74.8 & 2499 & 172 & $3: 34$ & 12.4 \\
\hline
\end{tabular}
different thermal stove properties, e.g. construction material of the heat exchanger. The lower heat storage capacity of stove A leads to a faster heat transfer to the surroundings. Thus, less heat is lost during the cool down phase. Differently for stove B the higher heat storage capacity leads to higher heat losses to the flue gas stack during cool down phase.

Table 5: Main results (thermal efficiency, $\mathrm{CO}$ and OGC emission factors, duration of cool down and share of THL during cool down) for all test runs. 
In terms of emissions, combustion conditions of stove B seems to be more favourable than for stove A. Over the whole test with closed dampers, stove B showed emission factors of $2408 \mathrm{mg} / \mathrm{MJ}_{\text {Output }}$ for $\mathrm{CO}$ and $109 \mathrm{mg} / \mathrm{MJ}_{\text {Output }}$ for OGC, whereas the emission factors of stove A were $2633 \mathrm{mg} / \mathrm{MJ}_{\text {Output }}$ for $\mathrm{CO}$ and $203 \mathrm{mg} / \mathrm{MJ}$ Output for OGC. The test of stove B without soap stone material showed similar levels of CO (2499 mg/MJ $\left.\mathrm{Jutput}_{\text {Ot }}\right)$, but higher levels of OGC (172 mg/MJ $\mathrm{Mutput})$ emissions.

The duration of the cool down phase was much longer for stove B due to its high heat storage capacity. Nevertheless, the share of THL during cool down (in relation to the total heat losses during heating operation and cool down) is much lower for stove B. Stove A, however, has an increased leakage rate which results also in an increased share of THL during the cool down phase.

Tests with open air supply dampers show similar results for thermal efficiency and OGC emissions. Stove A has higher efficiency and higher OGC emissions than stove B. However, $\mathrm{CO}$ emissions of stove A were lower than for stove B. The cool down phase of stove B remains longer, and shows increased heat losses. With open air supply dampers the air flow through the stove increases, which leads to a shorter duration of the cool down phase compared to the test with closed dampers. The higher air flow through the stove increases also the share of THL which occur in the cool down phase for all stoves under investigation.

\section{DISCUSSION}

\subsection{Influence of heat storage capacity}

The soap stone material of stove B was removed to decrease its heat storage capacity. As all other parameters remained the same (air supply damper settings - closed), the influence of this parameter could be evaluated. Main results of this test run are shown in Table 5.

Results indicate that the heat storage capacity influences thermal efficiency and emissions, as well as the duration and thermal losses during cool down. Without soap stones the efficiency of stove B is slightly higher, while $\mathrm{CO}$ emissions are almost on the same level. In contrast, OGC emissions are clearly higher in the test run without heat storage material. These results are in line with the comparison of the light and heavy stove in the test with closed air supply dampers. However, Fig. 4 shows that the heat storage capacity does not influence OGC emissions during cool down. More than $90 \%$ of OGC is emitted during heating operation. Therefore, the difference between both test runs originate from different combustion conditions during heating operation due to the used firewood. Furthermore, the duration of the cool down phase is shorter without soap stone material.

\subsection{User influence}

The settings of the air supply dampers at the end of heating operation were varied in order to evaluate one part of the user's influence.

As stove A has a very high leakage rate (Table 1) the differences between the test run with closed and the test run with left open air supply dampers are only marginal (an example for temperature is given in Fig. 2 - blue lines). Stove B is a room sealed appliance, therefore, the damper settings at the end of heating operation have a relevant influence on the cool down phase. Thus, when closing the air supply dampers the flue gas temperature suddenly decreased from about $240^{\circ} \mathrm{C}$ to $210^{\circ} \mathrm{C}$ (Fig. 2 - dark green line). Moreover, under pressure conditions in the calorimeter room, in relation to the surroundings, decreased abruptly from $9 \mathrm{~Pa}$ to $3 \mathrm{~Pa}$. It was observed that the velocity of the air inlet flow was decreasing from about 
$2.5 \mathrm{~m} / \mathrm{s}$ to $1 \mathrm{~m} / \mathrm{s}$, when the dampers were closed. This is due to the reduced volume flow, because of the stoves' tightness.

These facts also result in an accordant behaviour of the THL in the flue gas during cool down. Air supply damper settings had a bigger influence on stove B than on stove A. Fig. 3 shows the time dependent THL in the flue gas until the end of the test cycle. Over the whole test cycle (stove operation and cool down) stove B had more THL. At the end of heating operation, differences of user behaviour are observed at stove B. When dampers were closed, THL decreased to the lowest level of all four test runs, while with open dampers THL are highest.

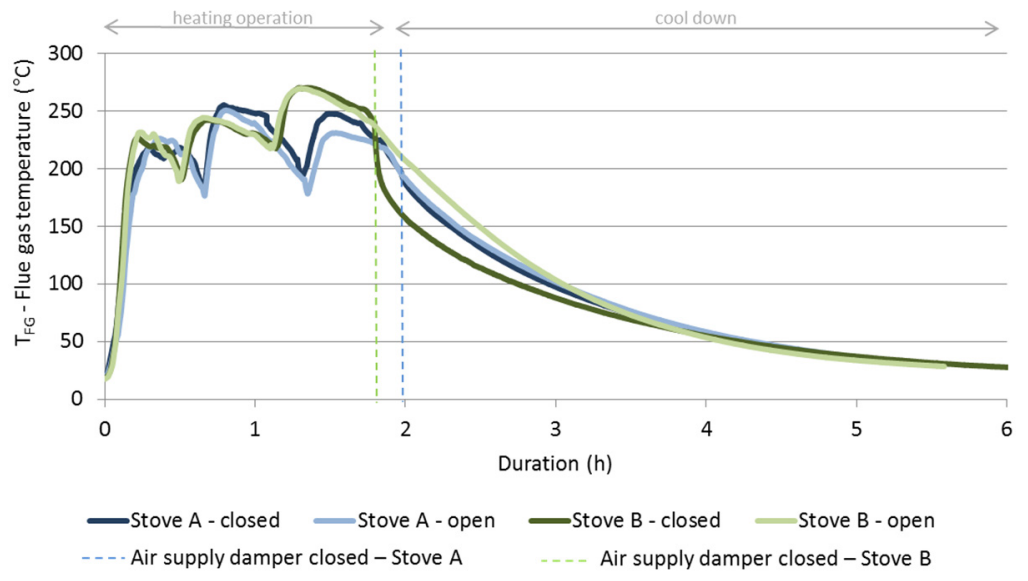

Figure 2: Time dependent flue gas temperatures (TFG) of the four main test runs during heating operation and cool down.

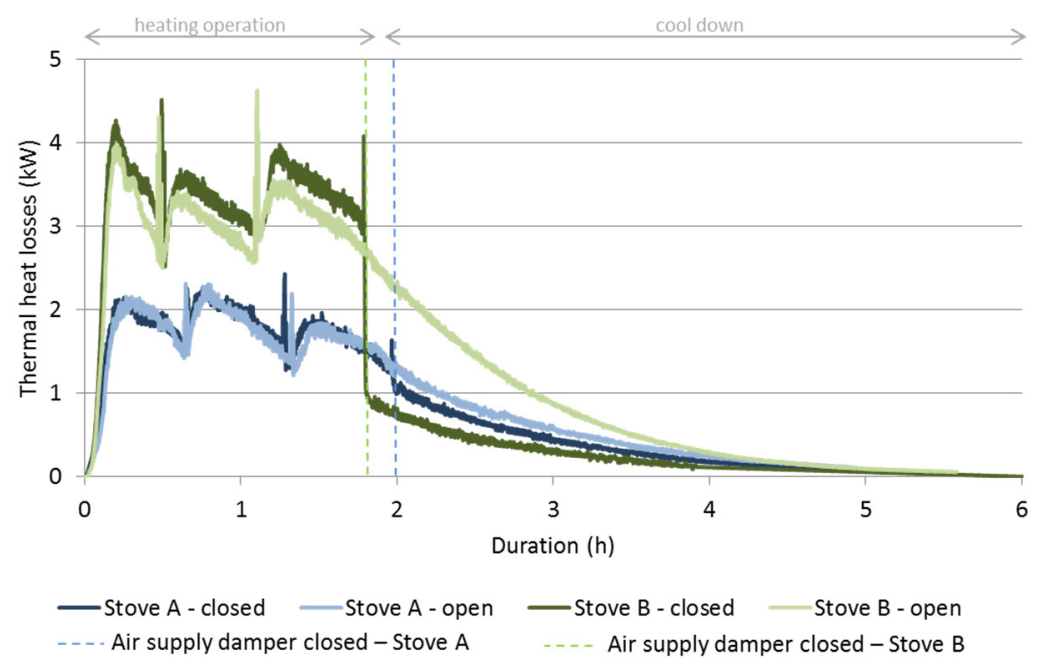

Figure 3: Time dependent THL of the four main test runs during heating operation and cool down. 
The damper settings clearly influenced the thermal efficiency of stove B. With open dampers the stove had a thermal efficiency of $68.3 \%$, whereas with closed dampers the efficiency was $73.3 \%$. Thus, an increase of 5.0 percentage points is possible only by closing the air supply dampers at the end of the heating operation. For stove A the differences are smaller, but even for this untight stove, an improvement of 1.1 percentage points is observable.

The duration of the cool down phase changed with different air supply damper settings. While for stove A the cool down lasted 16 minutes longer when the dampers were closed, stove B had a 29 minutes longer cool down phase when the dampers were closed after heating operation.

The closing of the air supply dampers at the end of the heating operation reduced the gaseous emissions (CO and OGC) of both stoves. The influence on emissions was higher for stove B than for stove A. Stove B shows a reduction of 36\% for CO and 33\% for OGC emissions, whereas for stove A the reduction for CO is $17 \%$ and for OGC $18 \%$.

Fig. 4 shows time dependent relative values for the cumulated $\mathrm{CO}$ (blue/green) and OGC (red/orange) emissions and the instant of time when closing the air supply dampers. It indicates that especially $\mathrm{CO}$ emissions are influenced by the cool down phase. The main part of OGC emissions arises during the 3 heating batches. The share of OGC during cool down is less than $10 \%$. For CO emissions the cool down accounts for 30 to $40 \%$ of the total emissions. Hence, air damper settings after heating operation as well as heat storage capacity have more influence on $\mathrm{CO}$ emissions than on OGC.

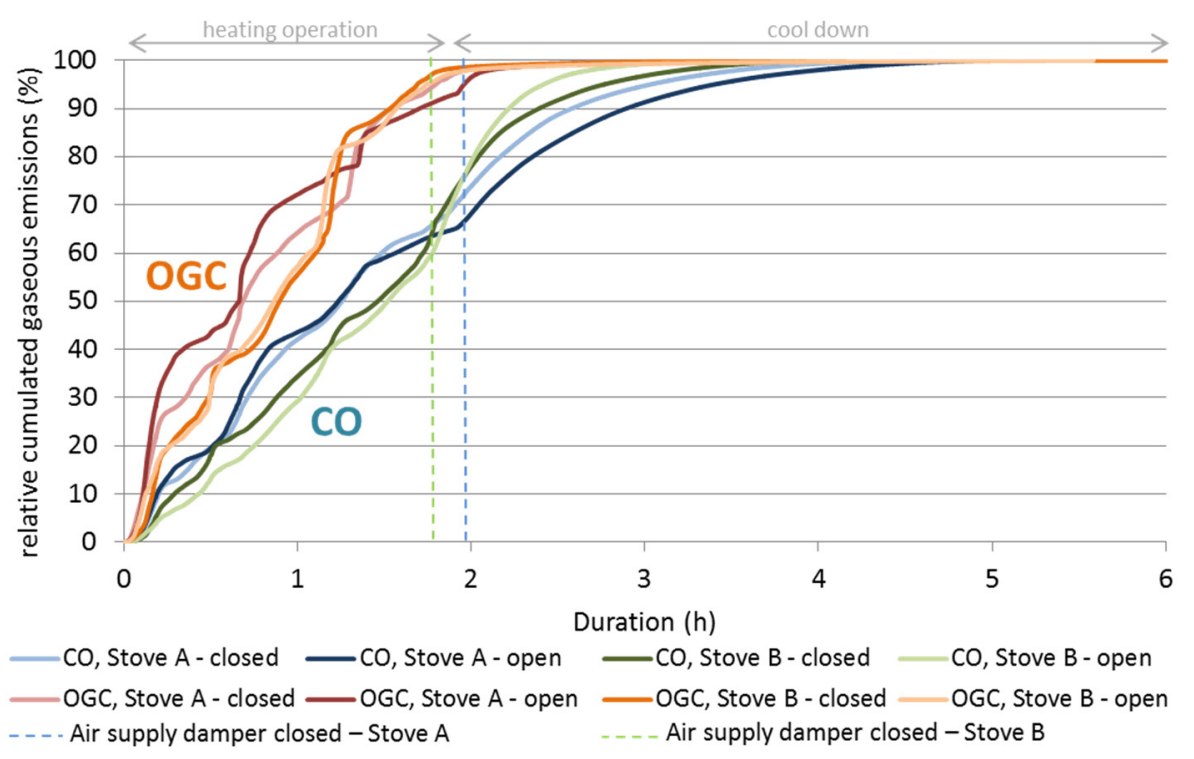

Figure 4: Time dependent CO and OGC emissions (volume-weighted, cumulated and relative values) for the four main test runs during heating operation and cool down. 


\section{CONCLUSIONS}

Emission factors of two different firewood room heaters were assessed, reflecting real life operation during autumn or spring season. Thereby, the influence of different properties of the stoves and moreover different user behaviour scenarios were evaluated.

1. Emission factors for stove A and B were compared. The light and untight stove A showed higher emissions and higher efficiency than the heavy and tight stove B. Moreover, stove B shows a characteristic long cool down phase. However, due to the low leakage rate, the heat losses during the cool down phase were comparably low at closed air supply damper settings.

2. At stove B the impact of heat storage capacity was demonstrated. The stove's performance showed differences in the results, especially regarding OGC emissions and the duration of the cool down phase, but also regarding efficiency.

3. The influence of the combustion conditions during cool down does only effect efficiency, THL and CO emissions. Since most of the OGC emissions ( $>90 \%)$ originate from the heating operation phase, the cool down has only marginal influence on this parameter.

4. By varying the air supply damper settings after heating operation the influence of the user was determined. As correct user behaviour can significantly increase the efficiency (up to 5 percentage points) and reduce emissions (CO), it is necessary to provide an applicable manual or organize training programs to instruct the users on how to operate their stove. Additionally, the influence of other user dependent parameters should be evaluated.

5. Depending on the leakage rate of the stoves, results indicate that the user influence on emissions and efficiency is higher than the influence of heat storage capacity. Thus, it is even more important to guarantee optimized user behaviour in real life operation of firewood room heaters.

6. As the cool down phase of a stove is real life relevant, further investigations are required in order to determine emission factors including cool down phase, under different real life scenarios (e.g. a typical winter heating day). Moreover, emission factors should also include particle matter (PM) and PAH emissions as these can negatively affect human health. More emission factors of different appliances, respecting real life conditions, should be evaluated. Hence, a database with those emission factors should be developed in order to use these values for dispersion models.

\section{ACKNOWLEDGEMENT}

The study leading to these results has received funding from the European Union in the Seventh Framework Program (FP7/2007-2013) under Grant Agreement no. 606605 (project beReal: www.bereal-project.eu) and from the Austrian Funding Agency under the COMET program.

\section{REFERENCES}

[1] Naeher, L.P., et al., Woodsmoke health effects: a review. Inhalation Toxicology, 19, pp. 67-106, 2007.

[2] Schmidl, C., et al., Particulate and gaseous emissions from manually and automatically fired small scale combustion systems. Atmospheric Environment, 45, pp. 7443-7454, 2011.

[3] Chiesa, M., et al., Integrated study through LCA, ELCC analysis and air quality modelling related to the adoption of high efficiency small scale pellet boilers. Biomass and Bioenergy, 90, pp. 262-272, 2016. 
[4] Spitzer, J., Enzinger, P., Fankhauser, G., Fritz, W., Golja, F. \& Stiglbrunner, R., Emissionsfaktoren für feste Brennstoffe - Endbericht, Graz, 1998.

[5] Meier, F., et al., Benzo(a)pyrene emission in the flue gas from modern biomass boilers. Proceedings of the $24^{\text {th }}$ European Biomass Conference and Exhibition, pp. 429-433 , 2016.

[6] Ozgen, S., et al., Analysis of the chemical composition of ultrafine particles from two domestic solid biomass fired room heaters under simulated real-world use. Atmospheric Environment, 150, pp. 87-97, 2017.

[7] Wöhler, M., et al., Investigation of real life operation of biomass room heating appliances - Results of a European survey. Applied Energy, 169, pp. 240-249, 2016.

[8] Reichert, G., et al., Investigation of user behavior and assessment of typical operation mode for different types of firewood room heating appliances in Austria. Renewable Energy, 93, pp. 245-254, 2016.

[9] Reichert, G., et al., Batch-wise wood combustion in firewood roomheaters - Impact of ignition mode and draught conditions. Presented at Word Sustainable Energy Days, Wels, Austria, 2016.

[10] Mitchell, E.J.S., Lea-Langton, A.R., Jones, J.M., Williams, A., Layden, P. \& Johnson, R., The impact of fuel properties on the emissions from the combustion of biomass and other solid fuels in a fixed bed domestic stove. Fuel Processing Technology, 142, pp. 115-123, 2016.

[11] ÖNORM EN 13240:2001 + AC:2003, Roomheaters fired by solid fuel - Requirements and test methods, Austrian Institute for Standardization, Vienna, 2003. 